\title{
The Effect of Different Polymers on the Drug Release Behavior from Fast Dissolving Amlodipine Besylate Oral Films for the Treatment of Hypertension
}

\author{
Rajasree $\mathrm{PH}^{1 *}$, Beenu Babu ${ }^{2}$, Arunkumar Nagalingam ${ }^{2}$ and Jessen George ${ }^{3}$ \\ ${ }^{1}$ Department of Pharmaceutics, JSS University, India \\ ${ }^{2}$ Department of Pharmaceutics, KMCH College of Pharmacy, India \\ ${ }^{3}$ Department of Water \& Health, JSS University, India
}

Submission: June 22, 2017; Published: June 29, 2017

*Corresponding author: Rajasree PH, Department of Pharmaceutics, JSS College of Pharmacy Mysore, Karnataka, India, Email: rajasreeph@gmail.com

\section{Introduction}

The antihypertensive effects of Calcium channel blockers (CCBS) have been used from decades [1]. Unlike BCS Class II drugs, Amlodipine is highly soluble Class III drug [2]. It is a second generation long acting dihydro calcium channel blocker used in the management of hypertension and angina pectoris The initial dose is $5 \mathrm{mg}$ dailyfor the management of hypertension. After the oral administration, it is well absorbed with a peak blood concentration of 6-12 hours having an elimination half-life of $30-50$ hours $[3,4]$.

Oral mucosal region is highly vascularized and it gives rapid absorption of drugs than oral route [5]. Drugs that are absorbed through the buccal mucosa and sublingual route directly enter the systemic circulation bypassing the first-pass metabolism in the liver [6,7]. Orally fast-dissolving film is new drug delivery system for the oral delivery of the drugs. It can be placed on the tongue or any oral mucosal tissue, instantly wet by saliva the film rapidly hydrates and adheres onto the site of application [8]. The aim of the study was to design, develop and evaluate rapidly dissolving oral films of Amlodipine besylate. The objective of the study is to develop an oral film for the immediate release of drug and to evaluate the effect of different polymers with disintegrates on the fabrication of the film and drug release from the film.

\section{Experimental}

\section{Materials}

Amlodipine was obtained as a gift sample from Microlabs, Bangalore. HPMC and SSG procured from LobaChemie Pvt. Ltd, Mumbai. PVA, sodium alginate, glycerin and propylene glycol from SD fine chemicals, Mumbai. PVP was purchased from SISCO Research Laboratories. All the other chemicals used were of analytical grade.

\section{Methods}

A. Formulation of Amlodipine fast dissolving oral film: Fast dissolving oral films of amlodipine was formulated using solvent casting method. The polymer HPMC (2\%, 2.5\% and $3 \%)$, PVA and PVP $(2 \%, 2.5 \%$ and $3 \%)$ and Sodium alginate and SSG $(1.5 \%, 2 \%$ and $2.5 \%)$ is dissolved in water and then the specified quantity of drug as well as plasticizers, other excipients were added and was air dried for 24 hours in petridishes.

B. Preparation of oral films using HPMC: HPMC $(2 \%, 2.5 \%$ and $3 \%$ ) were dissolved in water. Specified amount of drug and $20 \% \mathrm{w} / \mathrm{w}$ of plasticizers (glycerine, propylene glycol) were added to it. The above solution was poured onto a petridish and dried at room temperature. After 24 hours the dried films were taken out.

C. Preparation of oral films using PVA and PVP: PVA in percentage of $2 \%, 2.5 \%$ and $3 \%$ were dissolved in water. $1 \%$ and $2 \%$ PVP were added as disintegrates to each of the polymer solutions. Then $55 \mathrm{mg}$ of drug and $20 \%$ of plasticizers (glycerine, propylene glycol) were added to it. The above solution was poured onto the petridish and dried in oven at a temperature of $60^{\circ} \mathrm{C}$. After 24 hours the dried films were taken out.

D. Preparation of oral films using Sodium alginate and SSG: Sodium alginate in percentage of $1.5 \%, 2 \%$ and $2.5 \%$ were dissolved in water. Then $1 \%$ and $2 \%$ SSG was added to each of the polymer solution. Then $55 \mathrm{mg}$ of drug and $20 \% \mathrm{w} / \mathrm{w}$ of plasticizers (glycerine, propylene gycol) were added to it. The above solution was subjected to magnetic stirrer and was poured onto the petridish and was dried in room temperature and after 24 hours the dried films were taken out. 


\section{Results and Discussion}

The calibration curve of Amlodipine in Phosphate buffer pH6.8 at $238 \mathrm{~nm}$ (Figure 1) was carried out and $\mathrm{R}^{2}$ was found to be 0.996 .

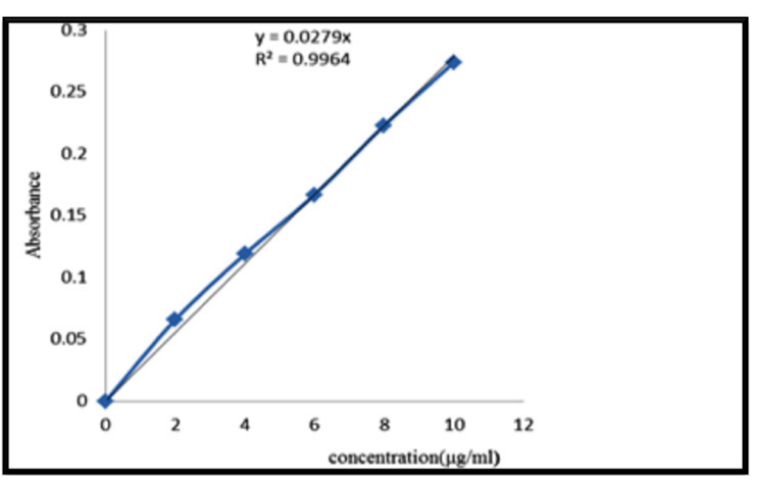

Figure 1: Calibration curve of Amlodipine in Phosphate buffer $\mathrm{pH} 6.8$ at $238 \mathrm{~nm}$.

Fast dissolving oral films were prepared by solvent casting method using polymers such as hydroxyl propyl methylcellulose, polyvinyl alcohol and sodium alginate using poly vinyl pyrrolidone and sodium starch glycolate as disintegrates.

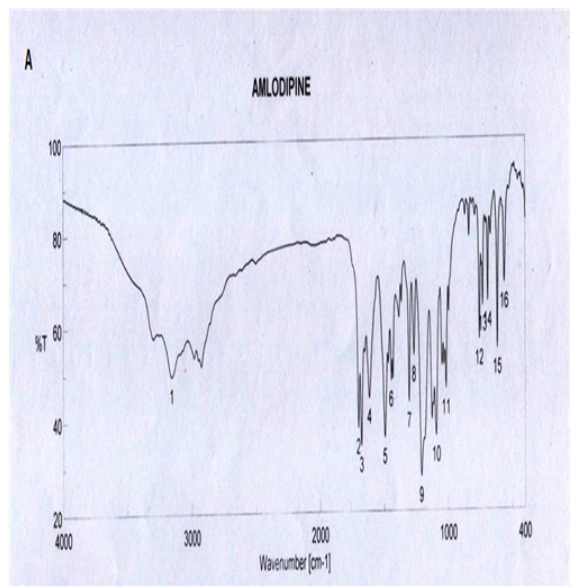

Figure 2: A. FT-IR spectra of Amlodipine (A) FT-IR spectra of formulation $(A)$.

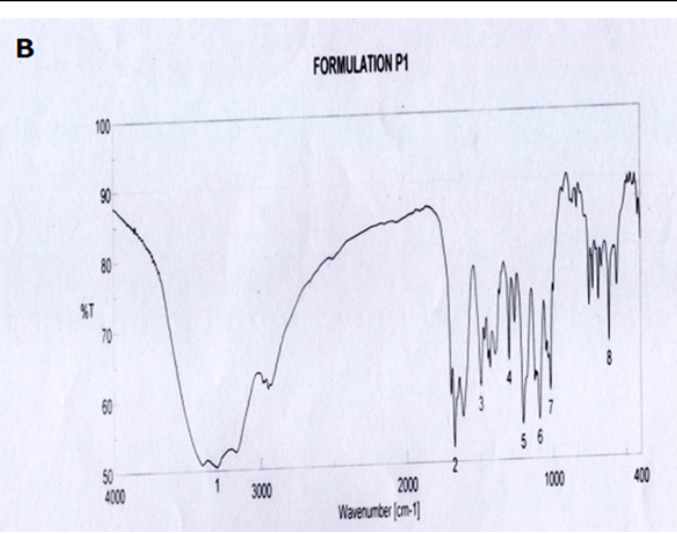

Figure 2: B. FT-IR spectra of Amlodipine (A) FT-IR spectra of formulation (B).
The FT-IR spectrum of the standard was analyzed and then superimposed with the samples to find out possible interactions between the drug and the polymers. All the characteristic peaks of Amlodipine were also found in the spectrum formulations Figure $2 \mathrm{~A} \& 2 \mathrm{~B}$. The results suggested that the drug is intact in the formulations and there was no interaction found between the drug and the excipients also the peaks in formulation showed slight variation due to the drug incorporation.

Table 1: Characteristic peaks of Amlodipine.

\begin{tabular}{|c|c|c|}
\hline Sl. No & $\begin{array}{c}\text { Wavelength } \\
\left(\mathbf{c m}^{-1} \mathbf{)}\right.\end{array}$ & Specification \\
\hline 1 & 3158 & Secondary -NH stretching \\
\hline 2 & 1092 & $\mathrm{C}-\mathrm{Cl}$ stretching \\
\hline 3 & 1698 & $\mathrm{C}=0$ stretching of ester \\
\hline 4 & 1570 & $\mathrm{NH}$ bending vibration \\
\hline 5 & 2926 & $\mathrm{CH}_{3}-\mathrm{CH}$ stretching \\
\hline
\end{tabular}

Table 2: Folding endurance of prepared HPMC, PVA and Sodium alginate films.

\begin{tabular}{|c|c|c|c|c|c|}
\hline $\begin{array}{c}\text { Formu- } \\
\text { lation } \\
\text { Code }\end{array}$ & $\begin{array}{c}\text { Folding } \\
\text { Endur- } \\
\text { ance }\end{array}$ & $\begin{array}{c}\text { Formula- } \\
\text { tion Code }\end{array}$ & $\begin{array}{c}\text { Folding } \\
\text { Endur- } \\
\text { ance }\end{array}$ & $\begin{array}{c}\text { Formula- } \\
\text { tion Code }\end{array}$ & $\begin{array}{c}\text { Folding } \\
\text { Endur- } \\
\text { ance }\end{array}$ \\
\hline H1 & 102 & P1 & 128 & S1 & 118 \\
\hline H2 & 115 & P2 & 132 & S2 & 108 \\
\hline H3 & 109 & P3 & 140 & S3 & 115 \\
\hline H4 & 105 & P4 & 130 & S4 & 120 \\
\hline H5 & 110 & P5 & 137 & S5 & 134 \\
\hline H6 & 116 & P6 & 146 & S6 & 126 \\
\hline
\end{tabular}

Table 3: Thickness of prepared HPMC, PVA and Sodium alginate films.

\begin{tabular}{|c|c|c|c|c|c|}
\hline $\begin{array}{c}\text { Formu- } \\
\text { lation } \\
\text { Code }\end{array}$ & $\begin{array}{c}\text { Thickness } \\
\text { (mm) }\end{array}$ & $\begin{array}{c}\text { Formula- } \\
\text { tion Code }\end{array}$ & $\begin{array}{c}\text { Thickness } \\
\text { (mm) }\end{array}$ & $\begin{array}{c}\text { Formula- } \\
\text { tion Code }\end{array}$ & $\begin{array}{c}\text { Thickness } \\
(\mathbf{m m})\end{array}$ \\
\hline H1 & 0.21 & P1 & 0.15 & S1 & 0.23 \\
\hline H2 & 0.23 & P2 & 0.17 & S2 & 0.25 \\
\hline H3 & 0.25 & P3 & 0.2 & S3 & 0.28 \\
\hline H4 & 0.2 & P4 & 0.16 & S4 & 0.25 \\
\hline H5 & 0.25 & P5 & 0.19 & S5 & 0.27 \\
\hline H6 & 0.28 & P6 & 0.22 & S6 & 0.29 \\
\hline
\end{tabular}

Table 4: Weight of prepared HPMC, PVA and sodium alginate films.

\begin{tabular}{|c|c|c|c|c|c|}
\hline $\begin{array}{c}\text { Formu- } \\
\text { lation } \\
\text { Code }\end{array}$ & $\begin{array}{c}\text { Weight of } \\
\text { the Film } \\
\text { (mg) }\end{array}$ & $\begin{array}{c}\text { Formu- } \\
\text { lation } \\
\text { Code }\end{array}$ & $\begin{array}{c}\text { Weight of } \\
\text { the Film } \\
\text { (mg) }\end{array}$ & $\begin{array}{c}\text { Formu- } \\
\text { lation } \\
\text { Code }\end{array}$ & $\begin{array}{c}\text { Weight of } \\
\text { the Film } \\
\text { (mg) }\end{array}$ \\
\hline H1 & 36 & P1 & 50 & S1 & 46 \\
\hline H2 & 40 & P2 & 58 & S2 & 51 \\
\hline H3 & 54 & P3 & 62 & S3 & 58 \\
\hline H4 & 40 & P4 & 54 & S4 & 51 \\
\hline H5 & 45 & P5 & 60 & S5 & 56 \\
\hline H6 & 56 & P6 & 64 & S6 & 61 \\
\hline
\end{tabular}

The physical evaluations and in-vitro drug release studies were performed for all the 18 formulations. The results are acceptable for folding endurance, thickness, weight uniformity, 


\section{Modern Applications of Bioequivalence \& Bioavailability}

percentage moisture absorption, disintegration time, drug content and in-vitro drug release shown in Table 1-5. The surface $\mathrm{pH}$ results of the film was found to be nearly neutral and suitable for oral use as shown in Table 6. Films were analyzed for its drug content and all the formulations showed a satisfactory drug content values ranging from $60-93 \%$ which is in accordance with the standard values prescribed for drug content analysis shown in Table 7.

Table 5: Percentage moisture absorption of HPMC, PVA and Sodium alginate films.

\begin{tabular}{|c|c|c|c|c|c|}
\hline $\begin{array}{c}\text { For- } \\
\text { mula- } \\
\text { tion } \\
\text { Code }\end{array}$ & $\begin{array}{c}\text { \% } \\
\text { Moisture } \\
\text { Absorption }\end{array}$ & $\begin{array}{c}\text { For- } \\
\text { mula- } \\
\text { tion } \\
\text { Code }\end{array}$ & $\begin{array}{c}\text { \% } \\
\text { Moisture } \\
\text { Absorption }\end{array}$ & $\begin{array}{c}\text { Formu- } \\
\text { lation } \\
\text { Code }\end{array}$ & $\begin{array}{c}\text { \% Moisture } \\
\text { Absorption }\end{array}$ \\
\hline H1 & 2.54 & P1 & 2.83 & S1 & 6.36 \\
\hline H2 & 4.77 & P2 & 5.36 & S2 & 9.65 \\
\hline H3 & 5.82 & P3 & 9.41 & S3 & 12.74 \\
\hline H4 & 3.15 & P4 & 3.5 & S4 & 7.48 \\
\hline H5 & 3.21 & P5 & 6.53 & S5 & 13.72 \\
\hline H6 & 4.97 & P6 & 8.61 & S6 & 12.78 \\
\hline
\end{tabular}

Table 6: Surface $\mathrm{pH}$ of prepared films of HPMC, PVA and sodium alginate.

\begin{tabular}{|c|c|c|c|c|c|}
\hline $\begin{array}{c}\text { Formula- } \\
\text { tion Code }\end{array}$ & $\begin{array}{c}\text { Surface } \\
\mathbf{p H}\end{array}$ & $\begin{array}{c}\text { Formula- } \\
\text { tion Code }\end{array}$ & $\begin{array}{c}\text { Surface } \\
\mathbf{p H}\end{array}$ & $\begin{array}{c}\text { Formula- } \\
\text { tion Code }\end{array}$ & $\begin{array}{c}\text { Surface } \\
\mathbf{p H}\end{array}$ \\
\hline H1 & 6.54 & $\mathrm{P} 1$ & 6.76 & $\mathrm{~S} 1$ & 6.67 \\
\hline $\mathrm{H} 2$ & 6.65 & $\mathrm{P} 1$ & 6.63 & $\mathrm{~S} 2$ & 6.84 \\
\hline H3 & 6.69 & $\mathrm{P} 3$ & 6.57 & $\mathrm{~S} 3$ & 6.55 \\
\hline H4 & 6.64 & $\mathrm{P} 4$ & 6.68 & $\mathrm{~S} 4$ & 6.71 \\
\hline H5 & 6.57 & P5 & 6.83 & $\mathrm{~S} 5$ & 6.73 \\
\hline H6 & 6.62 & P6 & 6.75 & S6 & 6.6 \\
\hline
\end{tabular}

Table 7: Assay of prepared HPMC, PVA and Sodium alginate films

\begin{tabular}{|c|c|c|c|c|c|}
\hline $\begin{array}{c}\text { Formulation } \\
\text { Code }\end{array}$ & $\begin{array}{c}\text { Assay } \\
\text { (\%) }\end{array}$ & $\begin{array}{c}\text { Formulation } \\
\text { Code }\end{array}$ & $\begin{array}{c}\text { Assay } \\
\text { (\%) }\end{array}$ & $\begin{array}{c}\text { Formulation } \\
\text { Code }\end{array}$ & $\begin{array}{c}\text { Assay } \\
\text { (\%) }\end{array}$ \\
\hline H1 & 96.35 & P1 & 97.67 & S1 & 96.82 \\
\hline H2 & 95.65 & P2 & 95.12 & S2 & 93.15 \\
\hline H3 & 93.84 & P3 & 92.03 & S3 & 91.34 \\
\hline H4 & 95.74 & P4 & 96.81 & S4 & 94.06 \\
\hline H5 & 92.87 & P5 & 94.69 & S5 & 92.26 \\
\hline H6 & 91.96 & P6 & 90.18 & S6 & 90.72 \\
\hline
\end{tabular}

Table 8: Disintegration time of prepared HPMC, PVA and Sodium alginate films.

\begin{tabular}{|c|c|c|c|c|c|}
\hline $\begin{array}{c}\text { Formu- } \\
\text { lation } \\
\text { Code }\end{array}$ & $\begin{array}{c}\text { Disinte- } \\
\text { gration } \\
\text { Time(sec) }\end{array}$ & $\begin{array}{c}\text { Formu- } \\
\text { lation } \\
\text { Code }\end{array}$ & $\begin{array}{c}\text { Disinte- } \\
\text { gration } \\
\text { Time(sec) }\end{array}$ & $\begin{array}{c}\text { Formu- } \\
\text { lation } \\
\text { Code }\end{array}$ & $\begin{array}{c}\text { Disinte- } \\
\text { gration } \\
\text { Time(sec) }\end{array}$ \\
\hline H1 & 20 & P1 & 15 & S1 & 42 \\
\hline H2 & 25 & P2 & 23 & S2 & 60 \\
\hline H3 & 40 & P3 & 30 & S3 & 80 \\
\hline H4 & 24 & P4 & 17 & S4 & 44 \\
\hline H5 & 31 & P5 & 26 & S5 & 57 \\
\hline H6 & 38 & P6 & 35 & S6 & 80 \\
\hline
\end{tabular}

Table 9: Dissolution study for HPMC films

\begin{tabular}{|c|c|c|c|c|c|c|}
\hline \multirow{2}{*}{$\begin{array}{c}\text { Time } \\
\text { (min) }\end{array}$} & \multicolumn{5}{|c|}{ Cumulative Percentage Drug Release } \\
\cline { 2 - 7 } & H1 & H2 & H3 & H4 & H5 & H6 \\
\hline 2 & 42.92 & 37.12 & 22.57 & 43.7 & 26.84 & 20.85 \\
\hline 4 & 51.56 & 43.74 & 37.89 & 54.78 & 41.56 & 39.17 \\
\hline 6 & 61.36 & 58.34 & 45.25 & 62.83 & 47.49 & 44.32 \\
\hline 8 & 72.68 & 65.1 & 52.54 & 70.54 & 58.76 & 51.61 \\
\hline 10 & 85.64 & 76.34 & 68.18 & 81.32 & 64.52 & 62.97 \\
\hline 15 & 90.56 & 83.87 & 75.45 & 90.93 & 74.06 & 73.1 \\
\hline 20 & 93.34 & 90.97 & 79.28 & 92.91 & 86.11 & 80.15 \\
\hline 25 & 93.32 & 93.45 & 90.64 & 93.92 & 92.12 & 87.84 \\
\hline 30 & 93.33 & 93.42 & 90.63 & 93.93 & 92.15 & 90.19 \\
\hline
\end{tabular}

Table 10: Dissolution study for PVA films.

\begin{tabular}{|c|c|c|c|c|c|c|}
\hline \multirow{2}{*}{$\begin{array}{c}\text { Time } \\
(\mathbf{m i n})\end{array}$} & \multicolumn{5}{|c|}{ Cumulative Percentage Drug Release } \\
\cline { 2 - 7 } & P1 & P2 & P3 & P4 & P5 & P6 \\
\hline 2 & 44.86 & 41.6 & 38.95 & 35.1 & 33.84 & 27.46 \\
\hline 4 & 50.15 & 49.93 & 45.72 & 45.78 & 40.5 & 35.17 \\
\hline 6 & 61.05 & 55.62 & 54.78 & 57.72 & 49.95 & 44.3 \\
\hline 8 & 74.75 & 66.15 & 65.11 & 65.14 & 58.76 & 50.78 \\
\hline 10 & 83.76 & 75.07 & 70.76 & 77.55 & 64.52 & 63.02 \\
\hline 15 & 93.88 & 86.91 & 81.05 & 81.62 & 78.86 & 75.87 \\
\hline 20 & 93.87 & 92.76 & 91.67 & 92.41 & 85.12 & 81.15 \\
\hline 25 & 93.85 & 92.75 & 91.66 & 92.42 & 91.73 & 87.84 \\
\hline 30 & 93.86 & 92.76 & 91.68 & 92.4 & 91.76 & 91.52 \\
\hline
\end{tabular}

Table 11: Dissolution study for Sodium alginate films.

\begin{tabular}{|c|c|c|c|c|c|c|}
\hline \multirow{2}{*}{$\begin{array}{c}\text { Time } \\
\text { (min) }\end{array}$} & \multicolumn{6}{|c|}{ Cumulative Percentage Drug Release } \\
\cline { 2 - 7 } & S1 & S2 & S3 & S4 & S5 & S6 \\
\hline 2 & 40.42 & 38.85 & 36.57 & 37.58 & 37.01 & 36.54 \\
\hline 4 & 46.66 & 44.73 & 41.58 & 44.29 & 43.58 & 41.93 \\
\hline 6 & 54.87 & 52.81 & 49.97 & 53.11 & 52.67 & 50.96 \\
\hline 8 & 65.06 & 63.9 & 57.85 & 62.74 & 61.75 & 59.87 \\
\hline 10 & 75.13 & 74.36 & 68.12 & 70.58 & 69.92 & 67.72 \\
\hline 15 & 86.54 & 84.65 & 72.37 & 81.85 & 78.75 & 75.3 \\
\hline 20 & 91.72 & 91.67 & 85.06 & 91.52 & 91.04 & 82.46 \\
\hline 25 & 91.74 & 91.68 & 91.42 & 91.53 & 91.03 & 90.94 \\
\hline 30 & 91.73 & 91.66 & 91.43 & 91.53 & 91.05 & 90.95 \\
\hline
\end{tabular}

The formulation P1 (2 \%PVA and 2\%SSG) was found to have the maximum disintegration time of $15 \mathrm{~min}$. The in-vitro release studies of formulation P1 showed maximum release of $93.86 \%$ within 30 minutes, which shows that the increase in polymer concentration decreases the drug release shown in Table 8-11. The kinetic data suggest that the formulation fit into 1st order equation for release of drug from the homogenous film and the release mechanism was found to be fickian diffusion. The stability studies showed that there was not much change in the physical appearance, drug content and dissolution When the oral film preparation was stored in a chamber controlled at $40{ }^{\circ} \mathrm{C}$ and $75 \%$ in humidity for 1 to 3 months, no apparent changes in the 
drug content, form or color of preparations were observed in Table 12. The drug content were was stable ranging from $97.67 \%$ to $93.96 \%$ during the study after storage at $40{ }^{\circ} \mathrm{C}$ and $75 \%$ humidity (accelerated condition). Therefore, the formulated Table 12: Stability studies of formulation P1.

\begin{tabular}{|c|c|c|c|c|c|c|c|c|c|c|}
\hline \multicolumn{11}{|c|}{ Condition: $40{ }^{\circ} \mathrm{C} \pm 2{ }^{\circ} \mathrm{C} / 75 \% \mathrm{RH} \pm 5 \% \mathrm{RH}$} \\
\hline \multicolumn{11}{|c|}{ Parameters observed for formulation P1 } \\
\hline Sl no: & Formulation & \multicolumn{3}{|c|}{ Physical appearance } & \multicolumn{3}{|c|}{ Drug content } & \multicolumn{3}{|c|}{ Dissolution } \\
\hline & & Initial & $1^{\text {st }}$ Month & $3^{\text {rd }}$ Month & Initial & $1^{\text {st }}$ Month & $3^{\text {rd }}$ Month & Initial & $1^{\text {st }}$ Month & $3^{\text {rd }}$ Month \\
\hline 1 & $\mathrm{P} 1$ & No change & No change & No change & 97.67 & 96.54 & 95.96 & 93.88 & 93.61 & 92.67 \\
\hline
\end{tabular}

\section{Conclusion}

A fast dissolving oral film of Amlodipine Besylate by solvent casting method was successful. Polymers such as HPMC, PVA and sodium alginate along with disintegrate like Poly Vinyl Pyrrolidone (PVP) and Sodium Starch Glycolate (SSG) were used. All physic-chemical studies of the prepared films are comparable within the range. The formulation P1 (2\%PVA and 2\%SSG) with maximum release rate was found to be the best formulation among the 18 formulations. Future studies using animal models will provide more effectiveness of the films in-vivo.

\section{Acknowledgement} College of Pharmacy, Kalappatty Road, Coimbatore, TN for providing the necessary facilities to carry out the research.

\section{References}

1. Suganeswari M (2011) Preparation, Characterization and Evaluation of Nanoparticles containing Hypolipidemic Drug and Antihypertensive Drug. International Journal of Pharmaceutical \& Biological 2(3): 949953.
The authors are likely to express sincere thanks to $\mathrm{KMCH}$
Amlodipine fast dissolving oral film using the combination of PVA and SSG would be a promising alternative for safer and effective treatment of hypertension.
2. Sebastain G, Rajasree PH, George J, Gowda DV (2016) Self Micron Emulsifying Drug Delivery Systems (SMEEDS) as a potential drug delivery system - Novel applications and future prespectives - A review. Int J Pharm 6(3).

3. Maheswari KM, Pavan Kumar D, Sravanthi D, Salma S, Naga Pravallika U, et al. (2014) Development and Evaluation of Mouth Dissolving Films of Amlodipine Besylate for Enhanced Therapeutic Efficacy. J Pharm (Cairo).

4. Diamantino Ribeiro S, Eliezer S, Jean-Louis V (2013) Control of hypertension in the critically ill: a pathophysiological approach. Ann Intensive Care 3(1): 17.

5. Patel Nibha K, Pancholi SS (2012) International Journal of Research in Pharmaceutical and Biomedical Sciences 3(2): 913-923.

6. Narang N, Sharma J (2011) Sublingual mucosa as a route for systemic drug delivery. Int J Pharm Pharm Sci 3 (2).

7. Hao Zhang, Jie Zhang, James B (2002) Oral Mucosal Drug DeliveryClinical Pharmacokinetics and Therapeutic Applications. Review Article Drug Delivery Systems Clinical Pharmacokinetics 41(9): 661680.

8. Malke M, Shidhaye S, Kadam VJ (2007) Formulation and evaluation of Oxacarbazine fast dissolve tablets. Ind J Pharm Sci 69(2): 211-214.

\section{Your next submission with Juniper Publishers will reach you the below assets}

- Quality Editorial service

- Swift Peer Review

- Reprints availability

- E-prints Service

- Manuscript Podcast for convenient understanding

- Global attainment for your research

- Manuscript accessibility in different formats

( Pdf, E-pub, Full Text, Audio)

- Unceasing customer service

Track the below URL for one-step submission https://juniperpublishers.com/online-submission.php 